\title{
Environmental Analysis and Diagnosis of Catfish Enterprises.
}

\author{
*Ogidi, Armstrong E. ${ }^{1}$ Adekitan, Rasheed ${ }^{2}$ and Odiba, Rita I. ${ }^{3}$ \\ ${ }^{I}$ Department of Agribusiness, University of Agriculture, P.M.B. 2373, Makurdi, Nigeria. \\ ${ }^{2}$ Department of Business Administration, University of Agriculture, P.M.B. 2373, Makurdi. \\ ${ }^{3}$ Department of Business Administration, University of Agriculture, P.M.B. 2373, Makurdi.
}

\begin{abstract}
The overall objective of this research is to carry out an environmental analysis and diagnosis of catfish enterprises in Benue State, Nigeria. A sample size of 143 catfish production enterprises was selected through simple stratified multi-stage random sampling design. A successful response rate of $79.7 \%$ was achieved as 114 of the questionnaires were considered acceptable. Majority of the respondents were of the opinion that government collaboration with local and foreign organizations was not enough and had produced a weak threat to catfish enterprises. Majority of the respondents had a strong threat view to the fact that interest rates, value of the Naira ( $\#)$ and tax rates discouraged new investment and business expansion. A more specific ETOP was developed for each key environmental factor by using the critical indices for each factor. This was done for determining the amount of opportunities and threats likely in the near future for five business environment features. Since most of the factors were positive, if the firm has the resources and competences, the obvious choice is to employ growth strategy. Managerial attitude towards risk and corporate politics are factors that could encourage growth strategy away from maintenance strategy.
\end{abstract}

Key words: Business cycles, environmental analysis, diagnosis, fiscal policies, technology

\section{Introduction}

The major basis for strategy formulation and strategic choice is the information gathered from environmental and enterprise analyses. The environments of organizations change often and firms must adapt to these changes to sustain their viability and to achieve success (Ottih, 2006b). The Business environment of catfish production from the broader, all inclusive perspective accommodates both the internal and external components. The external environment presents environmental opportunities and environmental threats ETOP analysis. This implies that the environment factor plays a decisive role in determining the success, failure and even continued existence of the business organization (Ottih, 2008). Business environment is seen to contain factors that influence policy decisions and activities of catfish enterprise production-unit (also referred to as the technical core of the enterprise). Government is also trying to encourage and support entrepreneurs involved in fish and fishery production in areas of capacity building, training, meeting market requirements and institutional personal training (Nigerian Pilot, 2012). Technological shifts can affect costs and quality or resource inputs, and stimulate further invention, innovation and competition. Technical support systems enable catfish producers to use and access technical information, to select and acquire technologies, equipment and production procedures, to adapt and control technology transfer and, finally, to capitalize on technological know-how (UNIDO A staff working paper, 2009).

\section{Objectives of the Study}

The overall objective of this research is to carry out an environmental analysis and diagnosis of catfish enterprises in Benue State, Nigeria. The specific objectives of the study include:

a) to explore the relevance of governmental/political/legal forces in predicting enterprise opportunity or threat in catfish enterprises,

b) to find out if economic variables influence business decisions regarding investment, expansion or diversifying the catfish enterprise,

c) to know the importance of market/competitive factors in taking decisions regarding standards, competition and demand for catfish,

d) to examine if new technology and the cost of technology affect the survival of the catfish enterprise, and finally

e) to ascertain if social/cultural/demographic/environmental frames drive trends that affect the catfish enterprise production.

\section{Research Hypotheses}

Ho $_{1}$ : governmental/political/legal forces are not significant in predicting enterprise threat to catfish enterprises.

$\mathrm{Ho}_{2}$ : economic variables are not significant in predicting enterprise threat to catfish enterprises.

$\mathbf{H o}_{3}$ : market/competitive factors are not significant in predicting enterprise threat to catfish enterprises. 
Ho : $_{\text {: }}$ technological factors are not significant in predicting enterprise threat to catfish enterprises.

Ho5: $_{5}$ social/cultural/demographic/environmental frames are not significant in predicting enterprise threat to catfish enterprises.

\section{A Brief Theoretical Review}

\section{Literature Review}

The objective of environmental analysis is to identify the key changes among the environmental factors of business and to recognize the opportunities and threats resulting from the changes. These obviously have strong impact on what directions organizations will choose to go and where not to go. According to David (1995), environmental forces can be divided into five key areas: a) Economic, b) Social, Cultural, Demographic, and Natural Environments, c) Political, Governmental and Legal, d) Supplier/Technological, and e) Market/Competitive forces. Diagnosis adds value to environmental analysis by assessing the significance of the data obtained from the environmental analysis. According to Ottih (2006a), it affords executives the opportunity and discretion to determine what data to consider as serious and which ones to consider as unserious and to drop. Tools have been designed for focusing the analysis for diagnostic purposes: a) Competitive Analysis (Porter's Five-Forces Model): according to Porter (1980), the intensity of competition in an industry is a clue to what companies in the industry will do, and the intensity of competition is determined by the following forces: i) rivalry among competing firms, ii) potential entry of new competitors, iii) potential development of substitute products, iv) bargaining power of suppliers and v) bargaining power of consumers. $\boldsymbol{b}$ ) Competitors Profiling: according to Lynch (1997), consumer power is increased when there is a concentration of consumers, when the products are undifferentiated and when the volume of purchases are large. In competitor profiling, the major competitor's objectives, resources, market strength and current strategies are analyzed. $\boldsymbol{c}$ ) Environmental Threats and Opportunity Profile (ETOP): Glueck (1980) developed a hypothetical ETOP for focusing analysis for diagnosis purposes. This study adopted this ETOP profiling for analyzing and diagnosing the environment of catfish enterprise business variables conceptualized for this study.

\section{Conceptualization}

\section{a) Government/Political/Legal Factors}

These entail the extent and process of government direct or indirect intervention and influence on businesses in an economy (Obiwuru et al. 2011). Governments have great influence on the infrastructure of a nation. According to Ottih (2008), the government and the laws, regulations and edicts of a country affect how businesses are operated in that country. Among the major aspects of the government/legal factor of influence are: (i) The Stability of Government: The stability of government creates an enabling environment for business operations and attracts additional domestic and foreign investments; the stability of government and the smooth change or political leadership makes it possible for business to predict and adapt to government policy shifts Ottih (2008). The instability of government is a serious threat to business and can drive away prospective local and foreign investments. The various changes in government which is a common feature in Nigeria are risks to the utilization of capacity by farmers; a stable policy must be ensured (Adedeji and Okocha, 2011). (ii)

Regulatory laws to protect indigenous catfish producers: Included in this component are discrimination law, consumer law, antitrust law, employment law, and health and safety law. These factors can affect how a company operates, its costs, and the demand for its products (Obiwuru et al. 2011). Tariffs, quotas and hurdles are imposed on foreign businesses to raise revenue for the government and to protect domestic producers (Ball et al. 2002). (iii) Collaboration: McClure (2001:29) stated that Power politics enters into a new business in the way that it does in forming a new government. Money brings power. Collaboration or partnership can be defined as structures for joint action in which complementary resources can be tapped and different interests can be balanced while the parties involved retain full independence (UNIDO, A staff working paper, 2009). The Nigerian government is collaborating with local and foreign organizations to boost the production of fish feeds and animal feeds (Nigerian Pilot, 2012). According to the report, Mrs. Folake Areola, the head of aquatic resources at Nigerian Agricultural Quarantine Services (NAQS), said that "the thrust of the collaboration was the effective use of local raw materials to produce feeds". She also narrated thus: "subsequently we will be putting out 1.2 billion fish feeds per annum; also there is the expectation that additional to what is being produced presently, Nigeria will be producing 250 metric tones of table-sized fish; this will help Nigeria to produce about 400,000 tones of fish feeds annually to meet the increase in the output of table sized-fish."

\section{b) Economic Factors}

The economic environment refers to the economic variables which influence the cost of doing business, the level of the profit obtainedable and the consumption level of buyers. These variables or indicators include the rate of increase of the economy of the nation as measured by the Gross Domestic Product (Ottih, 2008). (i) 
Fluctuations in the Business Cycle: Fluctuations are usually experienced in the economies of nations. They fluctuate from periods of prosperity or boom to recessions or depression and to recovery and back to a boom or a recession (Ottih 2008). These invariably affect such business decisions as whether or not to invest, expand or diversify the catfish enterprise, etc., and consumer decisions about what inputs resources to buy and how much to buy comes into consideration. (ii) Monetary and Fiscal Policies (interest rates, taxes, value of local currency etc.): These are economic policies relating to money supply, interest rate, value of the local currency, and tax rates for firms and individuals among other (Ball et al. 2002). High rates discourage new investments and business expansion, and low rates encourages them (Ottih, 2008). If individual tax rate are high, the purchasing power of consumers for catfish will slump and reduce patronage.

\section{c) Market/Competition Factors}

Fish marketing is controlled by women, except wholesale and distant trade that is dominated by men in inland communities (UNIDO A staff working paper, 2009). Products transportation is most commonly done through public transport. Catfish producers are sometimes forced to sell their catch to avoid preservation problems. The UNIDO draft report also stated that both fresh farmed catfish and smoked catfish are traded within Nigeria; reliable numbers are difficult to attain due to the large amounts that are unreported. (i) Increased Catfish Consumption: Catfish producers will have a high demand for their produce if income is evenly distributed in the population; thus improving the catfish value chain. Products are sold at a fixed price per kg. Fish producers in Nigeria are unable to meet demand for fish products, leaving Nigeria to rely heavily on import to help meet demand. Imports contribute between 650,000 to $700,000 t / y r$ (56\% of consumption). Nigerians consume about 1.2 million tones of fish per year. Fresh and processed fish is widely marketed throughout the country (UNIDO Draft Report, 2010). (ii) Cost Position and Competition for Resources in the Industry: When competition in an industry is high, more money is spent on such matters as formulated feeds, labor, experienced managerial consultants, research and development, advertising, market research, publicity and customer satisfaction. Market linkages is important for costs of input materials and first hand price; there are also important trade implications at both regional and international levels for the latter, the broader questions of competitiveness and international investments are important (NEPAD, 2008). Competition for resource inputs among catfish producers raises the costs of input resources. Competition among artisanal fishers is often muted due to the role played by traders who exercise a strong degree of control over prices. Rural fishers have very few alternatives but to sell their harvest to a trader. Collusion in price setting is very likely (UNIDO, Draft Repot 2010). There is a tendency for competitors to compete for imported catfish feeds when suppliers' stock reduces drastically. (iii) Standards: There is currently no standard and accreditation system for the inland artisanal fishery and small-scale fish farming, however, the Fisheries Society of Nigeria is participating in training course to enable them to undertake setting standards and providing accreditation (UNIDO Draft Report, 2010). Producers participating in global value chains are increasingly required to conform to a number of standards (Kaplinsky, 2004). In any given market, participants can seek voluntary standards and go through the formal certification process. Consumers might also request these voluntary standards or NGOs in the catfish sector in developing countries can also promote certification. Voluntary standards are verified through third-party auditing, as is the case of ISO (International Standard Organization). On the access of fish farmers to international market, the Federal Government of Nigeria would publish standards for the nation's fish and fish feed that would be globally competitive (Nigerian Pilot, 2012). (iv) Market Information: Adequate information on demand, supply and price conditions is necessary in a form that is easily understood by traders, consumers and farmers if catfish are to be distributed efficiently. Supportive educational and training programs are also needed to make market information services fully effective (Abdulai, 2006). A stable market will boost the development of the fish industry through a number of variable roles e.g. market services (information, intelligence reports, promotions etc.) so as to ensure sustained and increased inflow of investments and input resources (Adedeji and Okocha, 2011).

\section{d) Technological Factors}

Technology can be defined as the methods, machines or techniques used in the performance of a task. By this definition it refers to such things as techniques, tools, machines, instruments, appliances, ideas and manual methods used in getting a task accomplished (Ottih, 2008). They can determine barriers to entry, minimum efficient production level and influence outsourcing decisions (Obiwuru et al. 2011). Commercial farming has yet to become widespread in Nigeria (Fagbenro, 2005). At present, most fish farmers operate smallscale farms ranging from homestead concrete ponds (25-40 meters) to small earthen ponds (0.02-0.2 hectares). While there have been instances of successful introduction of technologies to boost production in Bangladesh (Thompson, Sultana and Khan, 2005) and Ghana (World Fish Centre, 2005); the major problem has been the lack of appropriate technology (Gupta, Bartley and Acosta, 2004; Toure and Noor, 2001; UNDP, 2004a). (i) Accessibility to New Technologies: Technological changes are also rife in terms of ideas, techniques and 
methods. Business organizations are advised to acquire new sets of useful technologies for more efficient operations or play the second fiddle (Obiwuru et al. 2011). The use of current technique, technology and processes confers competitive advantage of unequal measure on the firm in its procurement projects, design, concept and quality of inputs and products (Abdul and Abdul, 1999). For fish farmers, they would need information on fish farming technologies; in Nigeria agricultural information is available through National Agricultural Extension and Research Liaison Services (NAERLS). Fish farmers would need information on fish farming technologies, construction, management, breeds and spawning, processing, storage and marketing (Ofuoku et al. 2008). Many technologies require the production of inputs, intensive training in their use, or collective action. In Nigeria, several technology dissemination approaches have been practiced among which are the Ministry-based extension, commodity food approach, the commodity development approach among others (Ogunremi and Olaniran, 2012). According to Angba (2000) and Ogungbaigbe (2004) today technology dissemination approach is essentially based on the training and visit ( $\mathrm{T}$ and $\mathrm{V})$ methodology, which is as a result of the establishment of Agricultural Development Project (ADP). (ii) The Cost and Transfer of Technological Changes: The lack of capital investment is a major factor influencing the adoption of improved new technology. Catfish producers rely on personal savings and on traditional sources of credit (relatives, friends, money lenders, etc.) for investment capital. Nigerian aquaculture industry is too weak, technical training to promote advanced technologies is a gradual approach to the formation of a large industry scale (Tannet Business Development, 2012). The funds available at this level are limited and cannot meet the capital requirement of improved technology. As a result, catfish producers are unable to invest in new technologies that would raise productivity, allow micro-enterprises to expand and ultimately increase incomes (UNIDO A staff working paper, 2009). It is therefore necessary to ensure that improved fish production technologies that have been developed and disseminated are adopted, in order to increase fish production. While some scholars have stated that what is needed is to develop the technologies and make them available (Joshua and Omidiji, 2002), others insist that the transfer of technology would be more effective when there is a greater interaction among the developers, transfer agencies, and the farmers (Dlamini, 2003; Yap-Gnaore, Ehui and Shapiro, 1995). However, the crucial point is for the farmers to be able to afford any technology extended to them. A UNDP Report (2004b) indicated that it was the inability of farmers to afford the technologies extended to them that made farmers to abandon their ponds. Rogers (2003) has added another dimension by stating that the adoption of technology can be affected by the way it is named and positioned.

\section{f) Social/Cultural/Environmental/Demographic Factor}

The social and cultural factors focus on the values, attitudes, habits, religion, traditions, beliefs and developments among a people. These definitely influence business decisions, activities, and results, and are worth considering by any business executive (Ottih, 2008:61). a) Influence of demographic factors: Some of the demographic factors (i.e. cultural aspects such as age distribution, gender, educational attainment etc.) have great impact on the catfish production enterprises. b) Trends in social factors: These are the Trends (values, attitudes, social classes etc.) that affect the demand for a company's products and how that company operates (Obiwuru et al. 2011). An aging population may imply a smaller and less-willing workforce (thus increasing the cost of labor). Furthermore, the catfish enterprise may change various management strategies to adapt to these social trends (such as recruiting experienced workers to manage the enterprise).

\section{Materials And Methods}

\section{Sampling Technique and Sample Size}

In the first stage, the sampling frame was based on the division of Benue State into three zones (A, B and C). The sampling frame design was established with the help of the FAO (2007) list of catfish population (198) in Benue State and the Benue State Ministry of Agriculture. The three zones were then allotted their various catfish population sizes. The second stage of the sampling process entailed a disproportionate stratified sampling, where the number of elements allocated to the various zones is disproportional to the representation of the zones in the target population. The reason for using this method instead of the proportionate method is to increase the sampling size to a reasonable number. Thus, an independent simple random selection of $80 \%$ of catfish producers in each of the zones was selected in stage two. The third stage was followed by drawing out registered catfish enterprises and leaving behind unregistered enterprises. Thus a sample size of 143 catfish production enterprises was selected through simple stratified multi-stage random sampling design (see Table 1 below). 


\begin{tabular}{|c|c|c|c|c|c|c|c|c|}
\hline \multicolumn{3}{|c|}{ Stage 1} & \multirow{2}{*}{$\begin{array}{l}\text { Stage } 2 \\
\text { disproportionate } \\
\text { stratified sample } \\
\text { from population }\end{array}$} & \multicolumn{5}{|c|}{$\begin{array}{l}\text { Stage } 3 \\
\end{array}$} \\
\hline \multirow[t]{2}{*}{ Zone } & \multicolumn{2}{|c|}{$\begin{array}{l}\text { Population } \\
\text { proportion }\end{array}$} & & \multicolumn{4}{|c|}{$\begin{array}{l}\text { Collection of registered and } \\
\text { unregistered catfish enterprises }\end{array}$} & \multirow{2}{*}{$\begin{array}{l}\text { Sample of } \\
\text { Registered } \\
\text { Catfish } \\
\text { enterprises } \\
\text { selected for the } \\
\text { study }\end{array}$} \\
\hline & Freq & $\%$ & $(80 \%)$ & Overall & Reg. & Overall & Reg. & \\
\hline A & 36 & 18.0 & 29 & 21 & 19.0 & 8 & 7 & 26 \\
\hline $\mathrm{B}$ & 119 & 60.0 & 95 & 73 & 66.0 & 22 & 20 & 86 \\
\hline $\mathrm{C}$ & 43 & 22.0 & 34 & 23 & 21.0 & 11 & 10 & 31 \\
\hline TOTAL & 198 & 100.0 & 158 & 117 & 106.0 & 41 & 37 & 143 \\
\hline
\end{tabular}

Source: Field Survey, 2012

\section{Data Collection}

The main instrument for data generation and analysis was structured research questionnaire. Interview method and observation were also used to generate relevant qualitative data which revealed more information to compliment the questionnaires. All items were measured using a seven-point Likert-like scale ranging from lowest score $(-3=$ strong threat $)$ to highest score $(+3=$ strong opportunity).

\section{Validity and Reliability of Instrument}

Content validity ensured that the questionnaire fully exhausted all that are implied by the research questions in the questionnaire objectively, paying particular attention to the relevance of the subject matter and their coverage of the entire topic study. The Construct Validity of the statistical instrument generated data on each dimension and then tested for correlation among them. Reliability is the consistency between independent measurements of the same phenomenon.

\section{Data Analysis}

The extrapolated data from questionnaires were analyzed using computer-based Statistical Package for Social Sciences (SPSS) version 16. Chi-square was used to test the hypotheses for this study.

\section{Survey Response}

\section{Findings And Discussion}

A total of 143 questionnaires were sent out and 126 were retrieved; after careful scrutiny, 12 were rejected because; they were defaced. A successful response rate of $79.7 \%$ was achieved as 114 of the questionnaires were considered acceptable (see Table 2).

TABLE 2: QUESTIONNAIRE DISTRIBUTION AND RETRIEVAL

\begin{tabular}{cllll}
\hline & $\begin{array}{l}\text { Number } \\
\text { Administered }\end{array}$ & $\begin{array}{l}\text { Number } \\
\text { Retrieved }\end{array}$ & $\begin{array}{l}\text { Acceptance } \\
\text { Number }\end{array}$ & \% of Success \\
\hline TOTAL & 143 & 126 & 114 & $79.7 \%$ \\
\hline
\end{tabular}

Source: Field Survey, 2012

\section{Respondents Attitude towards Environment of Catfish Business a) Governmental/Political/Legal Factor}

Stability of government: the highest response, 47 (41.2\%) was for +1 , which means that government stability over time have not been too effective and provided a weak opportunity for catfish enterprises in Benue State. Regulatory laws to protect producers: most respondents, 61 (53.5\%) agreed that regulatory laws have been neutral (0) in protecting catfish enterprises. Government collaboration: majority of the respondents, 41 $(36.0 \%)$ were of the opinion that government collaboration with local and foreign organizations was not enough and had produced a weak threat (-1) to catfish enterprises (see Tables 3 and 4). The overall hypothetical ETOP of governmental/political/legal factors for catfish enterprises in Benue State was neutral (0).

\section{b) Economic Factors}

Fluctuations in the business cycles: most respondents, $41(36.0 \%)$ felt that fluctuations of boom to recessions and recovery had a neutral (0) effect on decisions as whether or not to invest, expand or diversify the catfish enterprise. Monetary and fiscal policies: majority of the respondents $55(48.2 \%)$ had a strong threat $(-3)$ view to the fact that interest rates, value of the Naira and tax rates discouraged new investment and business 
expansion. The overall hypothetical ETOP of economic factors for catfish enterprises in Benue State was strong threat $(-3)$.

\section{c) Market/Competitive}

Increased catfish consumption: majority of the respondents, $75(65.8 \%)$ agreed that the increased income distribution in the population had provided a strong opportunity $(+3)$ for catfish enterprises as demand tends to increase. Cost position and competition for resources: most respondents, $60(52.6 \%)$ were neutral (0) on the subject of competition within the catfish enterprise. This could have been intensified as competitors improve on advertising, market research, publicity, quality issues and customer satisfaction. Standards: conformance to standards took a considerable threat (-2) stance with majority of the respondents, $54(47.4 \%)$. It became even more difficult to seek voluntary standards and go through final market certification to penetrate the bigger market. Market information: the neutral (0) position taken by most of the respondents, 48 (42.1\%) implied that adequate information on demand, supply and price conditions had not been properly documented, packaged and disseminated to consumers, catfish enterprises and traders. The overall hypothetical ETOP of market/competitive factors for catfish enterprises in Benue State was strong threat $(+1)$.

\section{d) Technological}

Accessibility to new technology: majority of the respondents, $34(29.8 \%)$ believe that new technology provided a weak opportunity $(+1)$, because it aided the catfish enterprise to improve on its techniques, technology and processes; which confers competitive advantage of unequal measure in terms of procurement projects, design, concepts and quality of inputs and products. Cost and transfer of technological changes: most respondents $47(41.2 \%)$ had neutral (0) opinions as regards the cost and transfer of technology, because catfish producers rely on personal savings and traditional sources of credit for investment capital.

\section{e) Social/Cultural/Environmental/Demographic}

Influence of demographic factors: majority of the respondents, 47(41.2\%) agreed that demographic forces such as educational attainment and awareness of consumers as to the benefits of catfish consumption did boost the catfish enterprise and provided a neutral (0) and a weak opportunity (+1) for management to act upon. Trends in social factors: the largest number of respondents, 41(36.0\%) to a neutral (0) point of view, were of the opinion that trends in values, culture of consumers etc. improved the demand for catfish.

TABLE 3: SUMMARY OF RESPONDENTS ATTITUDE TOWARDS ENVIRONMENT OF CATFISH BUSINESS - AN ETOP LITMUSCHART

\begin{tabular}{|c|c|c|c|c|c|c|c|c|c|}
\hline & VARIABLES & -3 & -2 & -1 & $\mathbf{0}$ & +1 & +2 & +3 & Total \\
\hline \multirow[t]{4}{*}{1} & Governmental/Political/Legal & & & & & & & & \\
\hline & Stability of government & - & - & - & $\begin{array}{l}34 \\
(29.8)\end{array}$ & $\begin{array}{l}47 \\
(41.2)\end{array}$ & - & $\begin{array}{l}33 \\
(28.9)\end{array}$ & $\begin{array}{l}114 \\
(100)\end{array}$ \\
\hline & Regulatory laws to protect producers & - & - & $\begin{array}{l}26 \\
(22.8)\end{array}$ & $\begin{array}{l}61 \\
(53.5)\end{array}$ & - & - & $\begin{array}{l}27 \\
(23.7)\end{array}$ & $\begin{array}{l}114 \\
(100)\end{array}$ \\
\hline & Government collaboration & - & - & $\begin{array}{l}41 \\
(36.0)\end{array}$ & $\begin{array}{l}34 \\
(29.8)\end{array}$ & $\begin{array}{l}7 \\
(6.1)\end{array}$ & - & $\begin{array}{l}32 \\
(28.1)\end{array}$ & $\begin{array}{l}114 \\
(100)\end{array}$ \\
\hline \multirow[t]{3}{*}{2} & Economic & & & & & & & & $\begin{array}{l}114 \\
(100)\end{array}$ \\
\hline & Fluctuations in the business cycles & & $\begin{array}{l}28 \\
(24.6)\end{array}$ & $\begin{array}{l}20 \\
(17.5)\end{array}$ & $\begin{array}{l}41 \\
(36.0)\end{array}$ & $\begin{array}{l}25 \\
(21.9)\end{array}$ & - & - & $\begin{array}{l}114 \\
(100)\end{array}$ \\
\hline & Monetary and fiscal policies & $\begin{array}{l}55 \\
(48.2)\end{array}$ & - & $\begin{array}{l}26 \\
(22.8)\end{array}$ & $\begin{array}{l}33 \\
(28.9)\end{array}$ & - & - & - & $\begin{array}{l}114 \\
(100)\end{array}$ \\
\hline \multirow[t]{5}{*}{3} & Market/Competitive & & & & & & & & $\begin{array}{l}114 \\
(100)\end{array}$ \\
\hline & Increased catfish consumption & - & - & - & - & $\begin{array}{l}12 \\
(10.5)\end{array}$ & $\begin{array}{l}27 \\
(23.7)\end{array}$ & $\begin{array}{l}75 \\
(65.8)\end{array}$ & $\begin{array}{l}114 \\
(100)\end{array}$ \\
\hline & Cost position and competition for resources & - & $\begin{array}{l}14 \\
(12.3)\end{array}$ & $\begin{array}{l}27 \\
(23.7)\end{array}$ & $\begin{array}{l}60 \\
(52.6)\end{array}$ & $\begin{array}{l}13 \\
(11.4)\end{array}$ & - & - & $\begin{array}{l}114 \\
(100)\end{array}$ \\
\hline & Standards & - & $\begin{array}{l}54 \\
(47.4)\end{array}$ & $\begin{array}{l}13 \\
(11.4)\end{array}$ & $\begin{array}{l}33 \\
(28.9)\end{array}$ & $\begin{array}{l}14 \\
(12.3)\end{array}$ & - & - & $\begin{array}{l}114 \\
(100)\end{array}$ \\
\hline & Market information & - & $\begin{array}{l}6 \\
(5.3)\end{array}$ & $\begin{array}{l}26 \\
(22.8)\end{array}$ & $\begin{array}{l}48 \\
(42.1)\end{array}$ & - & $\begin{array}{l}34 \\
(29.8)\end{array}$ & - & $\begin{array}{l}114 \\
(100)\end{array}$ \\
\hline \multirow[t]{2}{*}{4} & Technological & & & & & & & & $\begin{array}{l}114 \\
(100)\end{array}$ \\
\hline & Accessibility to new technology & - & & $\begin{array}{l}27 \\
(23.7)\end{array}$ & $\begin{array}{l}25 \\
(21.9)\end{array}$ & $\begin{array}{l}34 \\
(29.8)\end{array}$ & $\begin{array}{l}28 \\
(24.6)\end{array}$ & - & $\begin{array}{l}114 \\
(100)\end{array}$ \\
\hline
\end{tabular}


Environmental Analysis And Diagnosis Of Catfish Enterprises.

5 Social/Cultural/Environmental/Demographic

\begin{tabular}{l|llll}
47 & 47 & 6 & 14 & 114 \\
$(41.2)$ & $(41.2)$ & $(5.3)$ & $(12.3)$ & $(100)$ \\
26 & 13 & 41 & 34 & 114 \\
$(22.8)$ & $(11.4)$ & $(36.0)$ & $(29.8)$ & $(100)$ \\
\hline
\end{tabular}

Trends in social factors

Key: colored portions $=$ critical indices $($ red $=$ threat, blue $=$ opportunity $),+=$ opportunity, $-=$ threat,$-3=$ strong threat, $-2=$ considerable threat, $-1=$ weak threat, $0=$ neutral, $+1=$ weak opportunity, $+2=$ considerable opportunity, $+3=$ strong opportunity

TABLE 4: A HYPOTHETICAL ETOP FOR CATFISH ENTERPRISES IN BENUE STATE.

\begin{tabular}{llcc}
\hline External Forces & $\begin{array}{l}\text { Extent of } \\
\text { Opportunity or } \\
\text { Threat }\end{array}$ & Summary \\
\hline 1 & Governmental/Political/Legal & +1 & $\mathbf{0}$ \\
& Stability of government & 0 & \\
& Regulatory laws to protect producers & -1 & $\mathbf{- 3}$ \\
& Government collaboration & 0 & \\
\hline 2 & Economic & -3 & $+\mathbf{1}$ \\
& Fluctuations in the business cycles & & \\
& Monetary and fiscal policies & +3 & \\
\hline 3 & Market/Competitive & 0 & $+\mathbf{+ 1}$ \\
& Increased catfish consumption & -2 & \\
& Cost position and competition for resources & 0 & +3 \\
& Standards & & \\
\hline 4 & Techet information & +1 & \\
& Accessibility to new technology & 0 & \\
& Cost and transfer of technological changes & & \\
\hline 5 & Social/Cultural/Environmental/Demographic & $+1,0$ & \\
& Influence of demographic factors & +2 & \\
& Trends in social factors & & \\
\hline
\end{tabular}

Key: $+=$ opportunity, $-=$ threat, $-3=$ strong threat, $-2=$ considerable threat, $-1=$ weak threat, $0=$ neutral,$+1=$ weak opportunity, $+2=$ considerable opportunity, $+3=$ strong opportunity

\section{Test of Hypotheses}

The five hypotheses were tested using chi-square test. Observed and expected outcomes were analyzed for each hypothesis; the following outcomes were arrived at as follows:

For the first hypothesis, $\mathrm{X}^{2}$ cal. $=\mathbf{1 1 2 . 7}$ and $\mathrm{X}^{\mathbf{2}}$ crit. $(\mathbf{5 \%})=\mathbf{7 . 8 1 5}$, which show that the study rejected the null hypothesis, "H0 $\mathbf{H}_{1}$ governmental/political/legal forces are not significant in predicting enterprise threat to catfish enterprises". This result implies that governmental/political/legal forces are significant in predicting enterprise threat to catfish enterprises (see Table 5).

For the second hypothesis, $\mathbf{X}^{2}$ cal. $=\mathbf{3 1 . 2 2 8}$ and $\mathbf{X}^{2}$ crit. $(\mathbf{5 \%})=\mathbf{7 . 8 1 5}$, which show that the study rejected the null hypothesis, "HO${ }_{2}$ : economic variables are not significant in predicting enterprise threat to catfish enterprises". This result implies that economic variables are significant in predicting enterprise threat to catfish enterprises.

For the third hypothesis, $X^{2}$ cal. $=\mathbf{1 0 6 . 1}$ and $X^{2}$ crit. $(\mathbf{5 \%})=\mathbf{1 1 . 0 7 0}$, which show that the study rejected the null hypothesis, "HO ${ }_{3}$ : market/competitive factors are not significant in predicting enterprise threat to catfish enterprises". This result implies that market/competitive factors are indeed significant in predicting enterprise threat to catfish enterprises.

For the fourth hypothesis, $X^{2}$ cal. $=\mathbf{1 0 . 2 4 6}$ and $X^{2}$ crit. $(\mathbf{5 \%})=\mathbf{7 . 8 1 5}$, which show that the study rejected the null hypothesis, "H0. enterprises". This result implies that technological factors are significant in predicting enterprise threat to catfish enterprises

Finally, for the fifth hypothesis, $X^{2}$ cal. $=9.789$ and $X^{2}$ crit. $\left.\mathbf{5 \%}\right)=\mathbf{7 . 8 1 5}$, which show that the study rejected the null hypothesis, "HO ${ }_{5}$ : social/cultural/demographic/environmental frames are not significant in predicting 
enterprise threat to catfish enterprises". This result implies that social/cultural/demographic/environmental frames are significant in predicting enterprise threat to catfish enterprises

TABLE 5: SUMMARY OF CHI-SQUARE HYPOTHESIS TESTS.

\begin{tabular}{|c|c|c|c|c|c|}
\hline & FACTOR INDICATOR & $\mathbf{X}^{2}$ & df & $P$ values & Decision \\
\hline 1 & $\begin{array}{l}\text { Governmental/Political/Legal } \\
\text { Stability of government } \\
\text { Regulatory laws to protect producers } \\
\text { Government collaboration }\end{array}$ & 112.7 & 3 & 0.000 & \\
\hline 2 & $\begin{array}{l}\text { Economic } \\
\text { Fluctuations in the business cycles } \\
\text { Monetary and fiscal policies }\end{array}$ & 31.228 & 3 & 0.000 & \\
\hline 3 & $\begin{array}{l}\text { Market/Competitive } \\
\text { Increased catfish consumption } \\
\text { Cost position and competition for resources } \\
\text { Standards } \\
\text { Market information }\end{array}$ & 106.1 & 5 & 0.000 & \\
\hline 4 & $\begin{array}{l}\text { Technological } \\
\text { Accessibility to new technology } \\
\text { Cost and transfer of technological changes }\end{array}$ & 10.246 & 3 & 0.017 & \\
\hline 5 & $\begin{array}{l}\text { Social/Cultural/Environmental/Demographic } \\
\text { Influence of demographic factors } \\
\text { Trends in social factors }\end{array}$ & 9.789 & 3 & 0.020 & \\
\hline
\end{tabular}

\section{Conclusion And Recommendations}

A more specific ETOP was developed for each key environmental factor by using the critical indices for each factor. This was done by determining the amount of opportunities and threats likely in the near future for five business environment features. The extent of opportunity or threat values are as follows: political/cultural/environmental $(0=$ neutral $)$, economic $(-3=$ strong threat $)$, market/competitive $(+1=$ weak opportunity), technological $(+1=$ weak opportunity $)$ and social/cultural/demographic/environmental $(+3=$ strong opportunity). Specifically, the study concluded that: a) Majority of the respondents were of the opinion that government collaboration with local and foreign organizations was not enough and had produced a weak threat to catfish enterprises. b) Majority of the respondents had a strong threat view to the fact that interest rates, value of the Naira and tax rates discouraged new investment and business expansion. c) Most of the respondents, implied that adequate information on demand, supply and price conditions had not been properly documented, packaged and disseminated to consumers, catfish enterprises and traders. d) Most respondents had neutral opinions as regards the cost and transfer of technology, because catfish producers rely on personal savings and traditional sources of credit for investment capital. e) Majority of the respondents agreed that demographic forces such as educational attainment and awareness of consumers as to the benefits of catfish consumption did boost the catfish enterprise and provided a neutral and a weak opportunity for management to act upon.

From our study, the following recommendations are necessary for improvement:

a) Since most of the factors were positive, if the firm has the resources and competences, the obvious choice is to employ growth strategy,

b) Risk averse executives may see the few neutral factors and choose the maintenance (stable growth) strategy,

c) Due to the neutrality of some of the scores, a seemingly equality and positives, especially in the government/political/legal factor, the maintenance or stable growth may as the most obvious choice,

d) Some bold and risk-taking executives may see the negatives in the analysis, but be encouraged by the neutrals and decide on a maintenance (stable growth) grand strategy, and finally

e) Managerial attitude towards risk and corporate politics are factors that could encourage growth strategy away from maintenance strategy.

\section{References}

[1] Abdul R. A. A. and Abdul A. H. (1999). Pengurusan Projek: Perspektif Industri pembinaan Pulau Pinang. Penerbit USM.

[2] Adedeji, O.B. and Okocha, R.C. (2012). Constraint to aquaculture development in Nigeria and way forward. Journal of Applied Science Research, 7(7):1133-1140.

[3] Angba, A.O. (2000). Determination of sustained use of selected technologies Recommended to farmersby Cross River State Agriculture development programme (ADP). Ph.D Thesis in the Department of Agricultural Extension and Rural Development, University of Ibadan, Nigeria.

[4] Ball, D.A., McCulloch, Jr. W.H., Frantz, P.L., Geringer, J.M. and Minor, M.S. (2002). International business: The challenge of global competition. ( $8^{\text {th }}$ ed.). New York, NY: McGraw-Hill/Irwin. 
[5] Dlamini, B. M. (2003). Effective linkages among national agricultural research institute, universities and extension systems; challenges and opportunities. In P.Anandajayasekeram \& R. J. Sebola (Eds.). Science and technology strategy for improved agricultural productivity and food security. (proc) South Africa/ Inter Academy council. Megaliesberg, South Africa.

[6] Fagbenro, O. A. (2005). Aquaculture in Nigeria: history, status and prospects. A report of FAO WorldFish Centre Workshop. Cameroon.

[7] FAO(2007).StateofWorldFisheriesandAquaculture.Retrievedfrom http://www.fao.org/fi/statist/fisoft/fishplu.asp.

[8] Gluek, W.F. (1980). Strategic management and business policy. New York: McGraw Hill Book Company. pp $44-50$.

[9] Gupta M.V, Bartley D.M and Acosta B.O (2004). Use of genetically improved and alien species for aquaculture biodiversity in Africa. World Food Centre. p.107.

[10] Joshua, A. and Omidiji, M.O. (2002). Rural development strategy in Nigeria, West and Central Africa. Paper presented at the international workshop on rural development in West and Central Africa. IITA, Ibadan. June 3-5.

[11] McClure, P. F. (2001). New Enterpreneur's Guidebook: Leading Your Venture to Business Success. USA: Financial World Publishing

[12] Nigerian Pilot (Friday, $24^{\text {th }}$ August, 2012). Federal Government partners local, foreign companiesonfish, animal feeds production. Accessed on the $29^{\text {th }}$ August, 2012 from www.nigerianpilot.com/index-php/business...

[13] Obiwuru, T.C., Oluwalaiye, O.B. and Okwu, A.T. (2011). External and internal environments of business in Nigeria: An appraisal. International Bulletin of Business Administration, EuroJournals, Inc., 12: 15-23. on the $29^{\text {th }}$ August, 2012 from http://www.eurojournals.com/IBBA.htm

[14] Ofuoku, A.N., Emah, G.N. and Itedejere, B.E. (2008). Information utilization among rural fish farmers in Central Agricultural Zone of Delta State, Nigeria. World Journal of Agricultural Sciences, 4(5):558-564.

[15] Ogungbaigbe, L.O. (2004). Research-Extension-farmer linkages for fruit technology transfer in selected states of south western Nigeria. Ph.D Thesis in the Department of Agricultural Extension and Rural Development, University of Ibadan, Nigeria.

[16] Ogunremi, J.B. and Olaniran, T.S. (2012). Research - extension - fish farmer linkage system in coastal and inland states of Nigeria. Journal of Applied Sciences Research, 8(3): 1853-1856.

[17] Ottih, L.O. (2006a). Organization theory: Structure, design and process. Port Harcourt, Nigeria: Amex Publications. 119 pp.

[18] Ottih, L.O. (2006b). General management: Strategy, implementation and control. ( $3^{\text {rd }}$ ed.).Nigeria. Port Harcourt: Pearl Publishers. 246 pp.

[19] Ottih, L.O. (2008). Modern business: An introduction. ( $2^{\text {nd }}$ ed.). Nigeria. Port Harcourt: PearlPublishers. 278 pp.

[20] Rogers, E. M. (2003). Diffusion of innovations (5th edition) Free Press: New York.

[21] Tannet Business Development (2012). Nigeria's aquaculture feasibility analysis report. Accessedon the $29^{\text {th }}$ August, 2012 from www.fcwc-fish.org/index.php\%3Foption\%3D

[22] Thomson, P. M., Sultana, P, \& Khan, A. K. M. (2003). Aquaculture extension impact in Bangladesh.World Fish Centre.

[23] Toure, M. K., and Noor, M. (2001). The role of agricultural technology in food and nutritional security on Africa. Journal of Food and Nutritional Security, 1 (1).

[24] UNDP (2004a). Equator Initiative www.tve.org/ho/doc, retrieved on February 2, 2006.

[25] UNDP (2004b). Sharing innovative experiences. Agricultural and rural development in the South. Accessed on the $29^{\text {th }}$ August, 2012 from http/tcdc.undp.org/experiences/vol5/improved, retrieved on December 2, 2006.

[26] UNIDO, A staff working paper (2009). Agro-value chain analysis and development the UNIDO approach. Italy, Vienna: Author. 83 pp.

[27] World Fish Centre (2005). Successful application of GIFT technology in Ghana and Malawi. Accessed on the $29^{\text {th }}$ August, 2012 from www.worldfishcentre.org/pubs/corporate

[28] Yap-Gnaore, V. C., Ehui, S. K., and Shapiro, B. (1995). Peri-urban livestock production and development in sub Sahara Africa: A review of opportunities and constraints. Tropical Veterinary Medicine, 1: 151-163 